\title{
INTELLIGENT IMPROVEMENT OF QUALITY MANAGEMENT FOCUSED ON COMPANY SOCIAL RESPONSIBILITY
}

\begin{abstract}
One of the principles and the basis of quality management is continuous improvement. The paper attempts to identify the intelligent improvement of quality management. According to the author the basis of an intelligent improvement is the knowledge resulting from the analysis of the needs and expectations of the company's stakeholders. In turn, stakeholders orientation is the basis of corporate social responsibility concept. Therefore, in the first part of the paper the relationship existing between the quality management and the concept of corporate social responsibility (CSR) is pointed out. In the second part the opportunity to improve quality management through the implementation of CSR principles is highlighted.
\end{abstract}

Key words: quality management, improvement, corporate social responsibility, stakeholders, PDCA cycle, Total Quality Management

\section{Introduction}

Companies that want to achieve market success in the difficult and ever-changing environment are looking for more and more new methods and management tools. Some of them decided to take the path towards business excellence. The way to achieve it is the practice of continuous improvement, which is the basic assumption of quality management. Improving quality management extends its goal of meeting the demands of customers to meeting the expectations of other stakeholders. Therefore, stakeholders analysis is necessary to allow identify and meet the needs of company's stakeholders. The stakeholders or interested parties are also the foundation of another, increasingly popular in the world concept of management - corporate social responsibility (CSR).

1 dr inż., Politechnika Śląska, Wydział Organizacji i Zarządzania,ve-mail: patrycja.habek@polsl.pl 
This concept is based on voluntary respect for the environmental and social impact when making business decisions while taking into account the expectations of stakeholders. So socially responsible company strives to maintain a state of balance between the expectations of many different stakeholders.

The aim of the paper is to present similarities between quality management and CSR concept and to point out how these two concepts can reinforce one another.

\section{Quality Management And Corporate Social Responsibility - Relationships}

Quality management can be defined as a holistic management philosophy that focuses on the maintenance and continuous improvement of all the functions within an organization, with the goal of meeting or exceeding the requirements of customer (FLYNN B. et al. 1994; KAYNAK H. 2003). Garvin (1988) describes how the scope of quality have changed in management thinking during the last century. In the first stage of the evolution of quality thinking, quality has been related primarily to the products or services, and the performances of those products and services. In the second stage of the evolution the view on quality was broadened to the processes by which the products and services were manufactured. Thus the focus shifted from the end of the production line to the process. The third stage was again a broadening of the focus from process to system. It was recognised that not only the primary production process influences the performances of the end product; the supporting, supplying, and management processes also act on that primary process and contribute to the products and services. The focus became the quality of the system. The fourth stage can be defined as the Total Quality Management (TQM) stage, where quality has become a more strategic issue and the focus is broadened towards the quality of the organisation and the quality of the organisation's relationships with its environment i.e. customers, suppliers, competitors, 
society (KOK P. et al. 2001). Furthermore different scholars suggest that quality management practices facilitate the development of environmental management (CURKOVIC S. 2003), require ethical behaviour (MCADAM R., LEONARD D. 2003), need a stakeholder focus (WADDOCK S., BODWELL C. 2004), and may facilitate the development of activities that are socially responsible (WITHANACHCHI N. et al. 2007; WOLNIAK R. 2013).

The second concept which is the subject of analysis in this paper is corporate social responsibility (CSR). The CSR concept is a broad term and differently defined (GAWEŁ E. et al. 2015). As an example guidance on social responsibility (ISO 26000: 2010) defines the concept as the responsibility of an organization for the impacts of its decision and activities on society and the environment, through transparency and ethical behaviour that: contribute to sustainable development, including health and welfare of society, takes into account the expectation of stakeholders, is in compliance with applicable law and consistent with international norms of behaviour, is integrated throughout the organization and practices in its relationship. European Commission understand it as a voluntary inclusion by business of social and environmental concerns in the commercial (economic) activities and their relation with their stakeholders (GREEN PAPER 2001).

Referring to the above definitions, it seems that a key aspect of the CSR concept is running a business based on building lasting and transparent relationship with all stakeholders (HĄBEK P. 2009). Therefore it can be concluded that responsibility is already being managed when, for example, employee policies are developed, when customer relationship strategies are implemented, when supply chains are managed, when leaders are really committed to a quality culture, when firms manage processes to achieve quality improvement, and when firms use measurement systems to improve their activities (TARI J. 2011).

Therefore, it may be identified some common points between quality management and CSR concept. Some of them are discussed below. 


\section{TQM philosophy and core values}

The founders of modern quality management and business excellence, Crosby, Deming and Juran, believe that ethics, principles and respect for people are the key rules of conduct. Deming in his 14 Principles advocate organizational climate where interests between managers, employees and customers are conducted in accordance with ethical principles. Juran talked about system consisting of values, attitudes and behavior, individual and collective, created within the organization, which are necessary for organizational success. He opted for the view that TQM should be recognized by focusing on the people, manifested in the quality of working life and satisfaction of employees (MCADAM R. 2003).

Concepts based on the principles do not distract from searching the profits but they put more emphasis on sustainable results by valuing people and the environment (MOLENDA M. 2012). The concept of total quality management is similar to the concept of social responsibility as it has ethical basics which are necessary in the development of socially responsible company. Philip Crosby argued that quality is free. Good treatment of people is also for free and social responsibility is about improving relations with company's stakeholders who can significantly influence its success.

CSR has a "strong affinity with the founding principles of quality management" through ethics, values-based governance, and respect for people (LEONARD D. MCADAM R. 2003). The philosophies of, for example, Deming, Crosby, and Juran all lay testament to this. Crosby discusses the importance of integrity; Juran speaks of a system of values, beliefs, and behaviours that are necessary for organizational success. Ishikawa (1985) makes a particularly strong statement on behalf of CSR when he asserts that, "the first concern of a company is the happiness of the people connected to it. If the people do not feel happy, that company does not deserve to exist". In a related vein, Jacques (1999) asserts that "for many people, the tremendous appeal of quality is the opportunity to do good - to improve the workplace, to raise standards of living and to 
achieve excellence". This same assertion also applies to socially responsible organisations (HAZLETT S. et al. 2007).

This all implies that CSR could be a natural progression for those organisations that have already begun their interest in quality. The "quality journey" (DALE B., LASCELLES D. 1997) is portrayed as having an overall element of continuous improvement where organisations both develop and use quality management in an increasingly complex and sophisticated manner; in many respects progressing from quality assurance, through TQM to business excellence and now, socially responsible business (HAZLETT S. et al. 2007).

\section{Quality awards and excellence models}

The issue of social responsibility is becoming a theme for organisations which are serious in their approach towards business excellence (FISSCHER O. 1994; BUBAN M. 1995; NAKANO C. 1999). Existing models of excellence used in quality awards include the main elements of the concept of social responsibility. For example Malcolm Baldrige American Quality Award model includes issues of social responsibility in terms of criteria: Leadership (1.3 "collective responsibility and citizenship"). Questions related to this criterion and their context with leadership emphasize the importance of social responsibility and its place in the daily practice of business. In this criterion it should be presented how the company turns its responsibility for society in the quality policy and the improvement practices as well as how the company leads as a corporate citizen in key communities (FOSTER D., JONKER J. 2003). Issues related to the impact of business on society have been also widely incorporated in the model of excellence of European Quality Award within a criterion, called "Society Results". The general mission of the EFQM (the European Foundation for Quality Management) Excellence Model is to help organizations in their efforts for excellence and increased competitiveness. The relationship between the corporate social responsibility concept and the EFQM Excellence 
Model has been identified by Cierna and Sujova (2015). It can be summarised within the scope of the following areas:

- improve corporate culture and responsibility for all actions, products and services,

- draft ethical codices and their real-life application,

- motivate to maintain commitments towards partners and suppliers,

- develop a code of conduct and examples of behaviours in professional and personal life,

- personal participation in corporate, socially responsible activities,

- take advantage of partnership to raise awareness of socially responsible activities,

- participate in professional activities targeting social activities,

- systematically evaluate development of the field of corporate social responsibility,

- establish commitments and close cooperation with business subjects by identifying needs and expectations in corporate, social activities,

- identify and understand moving parts in socially responsible activities and set priorities for changes in this area,

- delegate personal responsibility for socially responsible business activities, and

- ensure cooperation with internal and external customers as part of corporate social responsibility.

It can be concluded that systematic and professional work with the EFQM Excellence Model brings maximum value to all interested parties in relation to corporate social responsibility (CIERNA H., SUJOVA E. 2015).

ISO 26000, PDCA cycle, continuous improvement

Next relation between quality management and CSR can be seen in the principle of continuous improvement. International standard on quality management system ISO 9001 is based on the Deming PDCA 
cycle - a model showing the mechanism of continuous improvement. Guidance on social responsibility ISO 26000 is based on the same rules. ISO 26000 guidance requires to put in place processes, systems and structures that make it possible to apply the principles and practices of social responsibility. The PDCA cycle is useful for ensuring that this work is an ongoing process (MICHALSKI K., SITKO J. 2012). One of the keys to success in working with ISO 26000 is to ensure the commitment from top management. They must be engaged and take ownership of the framework and the approach to integrate social responsibility principles into practice. Moving to the top right corner of the PDCA cycle, the PLAN phase starts off by analysing which are the most significant core subjects (core subjects according to ISO 26000 are: organizational governance, human rights, labour practices, the environment, fair operating practices, consumer issues, community involvement and development) for the organisation and understanding why. This is a critical first step before one can decide how to manage them. The DO phase focuses on raising awareness in the organisation and taking action in the chosen areas. The CHECK phase should ensure monitoring the impact of undertaken activities and evaluate progress. In the ACT phase it should be reviewed and updated the approach, before continuing the cycle (DNV 2010).

Summarizing implementation of CSR concept can be based on the Deming PDCA Cycle which is used inter alia in quality management. 


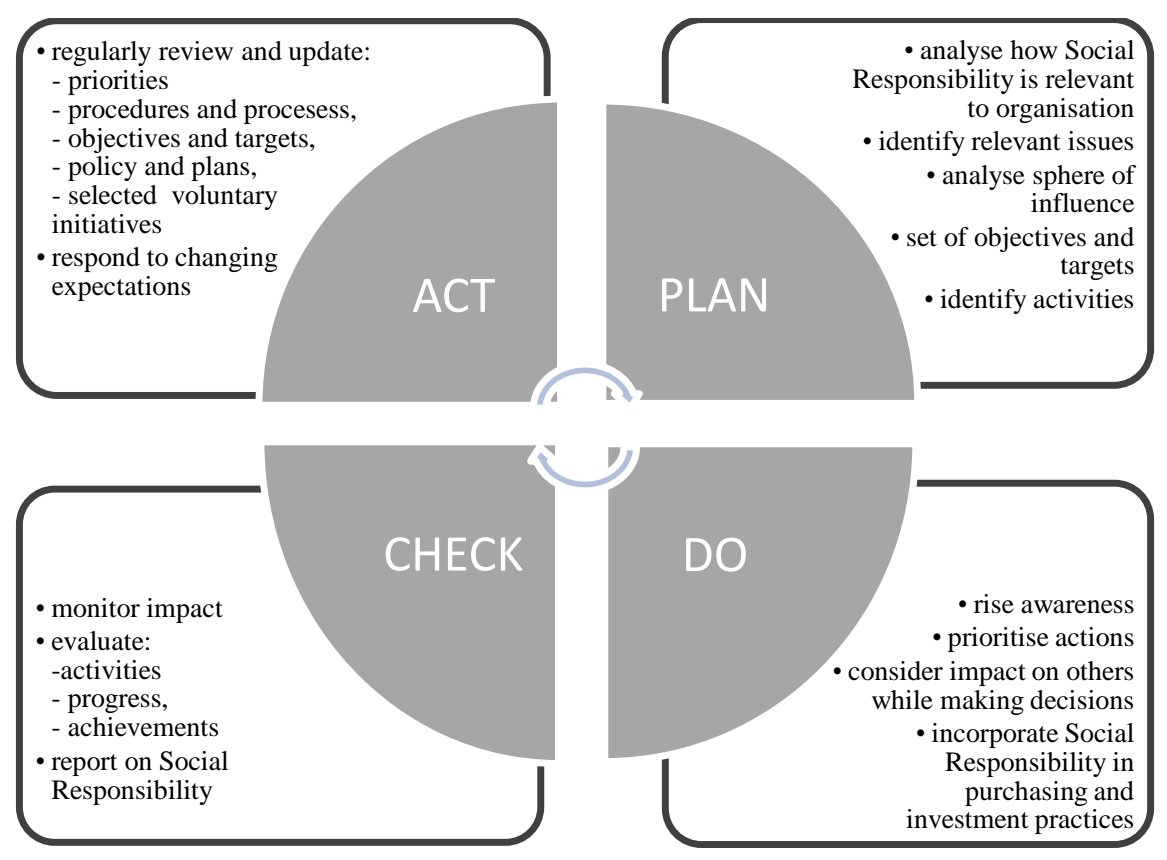

Fig. 1. PDCA cycle in social responsibility implementation.

Source:http://www.dnvba.com/my/DNV\%20\%20Downloads/ISO26000brochure.pdf, 29.02.2016

Sustained success of an organization - ISO 9004:2009

International standard ISO 9004:2009 - Managing for the sustained success of an organization. A quality management approach is based on the premise that satisfying the customer can bring success, but to achieve sustainable success the organization needs to go much further and satisfy the needs and expectations of all stakeholders. In pursuit of achieving sustainable success the standard proposes to use the principles of quality management. According to the standard the sustainable success of an organization is achieved by its ability to meet the needs and expectations of customers and other interested parties (stakeholders), in the long term and in a sustainable way. Sustained success can be achieved by the effective management of the organization, through awareness of the 
organization's environment, by learning and by proper application of improvements and /or innovations (ISO 9004:2009). The standard strongly highlights the issue of organization's stakeholders, or as they are defined in the standard - interested parties. Issues related to stakeholders has been placed at the beginning of the standard, because of their direct importance for the organization now and in the future. We can say that the stakeholders are the part of its identity. Changes affecting any of the stakeholders affect the functioning of the organization (ROBITAILLE D. 2010). Referring it to the CSR concept it's foundations are based on stakeholders theory (HĄBEK P. 2009).

\section{Intelligent Improvement of Quality Management}

One of the key features of the current generation of quality management is the emphasis on the holistic nature of management. This is reflected in the literature of total quality management (TQM) in the use of the word "total" as well as in the holistic nature of quality awards (D. FOSTER, JONKER J. 2003). Implementation of the concept of total quality management (TQM) extends the range of stakeholders of the organization. The result of improving the quality management systems (QMS) functioning in the enterprise QMS is the move from meeting the customer needs and expectations to create value for all stakeholders, including the local communities. Enterprises conduct their activities in a social network of stakeholders, which has the force of both direct and indirect impact on their success (ZADEK S. 2003).

Chapter nine of ISO 9004: 2009 - improvement, innovation and learning goes beyond the scope relating to the improvement of the QMS based on the requirements of the ISO 9001 standard and refers to innovation and learning, two important issues for any organization whose objective is to achieve sustainable success (HOYLE D. 1994). Organizational learning is more than the sum of individual abilities and learning skills of individual employees (LASZLO CH. 2009). Learning organization is an organization enhancing its flexibility, continually 
adapting, transforming to changes in the environment (MIKUŁA B. et al. 2002). The learning process makes the organization gains new possibilities for perceiving itself and the stakeholders who become partners in the search for sustainable value and innovations that lead to it.

What is needed is the openness to new ideas from all the stakeholders affected by the process or product - from customers to suppliers. This also applies to the use of feedback, which flows to the company. In the stakeholder-oriented organization the level of innovation increases by enabling participation of stakeholders inside and outside the company (LASZLO CH. 2009).

In ISO 9004 standard the source of organization success is "its ability to meet the needs and expectations of its customers and other interested parties, over the long term and in a balanced way" (ISO 9004: 2010). An important element that appears in ISO 9004 are interested parties (stakeholders) who bring value to the organization, are otherwise interested in the activities of organizations or which are affect by the organization (ISO 9004: 2010). To achieve sustained success an organization must manage the relationships with stakeholders and answer to needs and expectations coming from the environment. Such understanding of excellence in the context of quality management is consistent with the basic assumptions of corporate social responsibility concept where stakeholders and their requirements are in focus of the organization (RUDNICKA A., REICHEL J. 2012).

\section{Conclusions}

The paper shows that exists links between the quality management and the concept of social responsibility both at the level of philosophy and the values underlying these concepts as well as solutions used at the operational level. An important but not fully recognized issue underlying both of these concepts is the analysis of needs and expectations of organizations' stakeholders. As we know the only certain feature of the present environment of the organization is its changeability. To achieve 
sustained success, companies should acquire the ability to adapt to constantly changing conditions. Timely detection of changes in the environment will help reduce business risk. This is possible, among others, thanks to identifying the needs and expectations of stakeholders and conducting an ongoing dialogue with them. These actions allow to acquire the knowledge necessary to improve the management of socially responsible organization. Taking into account the above findings intelligent improvement of quality management is based on knowledge resulting from the analysis of needs and expectations of stakeholders.

\section{Bibliography}

1. BUBAN M. 1995. Factoring Ethics into the TQM Equation. "Quality Progress" 28(10), 97-99.

2. CIERNA H., SUJOVA E. 2015. Parallels Between Corporate Social Responsibility and the EFQM Excellence Model. "MM Science Journal", 10/2015, 670-676 DOI: 10.17973/MMSJ.2015_10_201533

3. CURKOVIC S. 2003. Environmentally Responsible Manufacturing: The Development and Validation of a Measurement Model. "European Journal of Operational Research" 146, 130-155.

4. DALE B. LASCELLES D. 1997) Total quality management adoption: revisiting the levels. "The TQM Magazine" 9(6), 418-28.

5. DNV

http://www.dnvba.com/my/DNV\%20\%20Downloads/ISO26000brochur e.pdf, dostęp 29.02.2016

6. FISSCHER O. 1994. Ethics and Social Value. "European Quality" 1(4), 34-36.

7. FLYNN B. B., SCHROEDER R. G., SAKAKIBARA S. 1994. A Framework for Quality Management Research and Associated Measurement Instrument. "Journal of Operations Management" 11, 339-366.

8. FOSTER D., JONKER J. 2003. Third generation quality management: the role of stakeholders in integrating business into society. "Managerial Auditing Journal" 18/4. 
9. GAWEŁ E., JAŁOSZYŃSKA A., ORŁOWSKI M., RATAJCZAK E., RATAJCZAK J., LARA RIERA B. 2015. Spoleczna odpowiedzialność biznesu jako instrument zrównoważonego rozwoju przedsiębiorstw produkcyjnych. „Management Systems in Production Engineering” 3(19) DOI 10.12914/MSPE-07-03-2015

10. GREEN PAPER. 2001. Promoting a European Framework for Corporate Social Responsibility. Bruksela, http://eurlex.europa.eu/legal-content/EN/TXT/?uri=URISERV\%3An26039, dostęp 21.03.2016.

11. HĄBEK P. 2009. Spoleczna odpowiedzialność przedsiębiorstw jako koncepcja firmy zorientowanej na interesariuszy. „Organizacja i Zarządzanie”. Wydawnictwo Politechniki Śląskiej 2(6), 69-86.

12. HAZLETT S.A. , MCADAM R., Murray L. 2007. From quality management to socially responsible organisations: the case for CSR. "International Journal of Quality \& Reliability Management" 24(7), 669 - 682, DOI http://dx.doi.org/10.1108/02656710710774665

13. HOYLE D. 1994. ISO 9000 Quality Systems Handbook. Butford Technical Publishing. Bodenham.

14. ISHIKAWA K. 1985. What is total quality control?. The Japanese Way. Prentice-Hall. Englewood Cliffs.

15. ISO 26000:2010. 2010. Guidance on Social Responsibility. ISO, Geneva.

16. ISO 9004:2009. 2009. Managing for the sustained success of an organisation - $A$ quality management approach, http://www.singaporestandardseshop.sg/data/ECopyFileStore/09121708 5950Preview\%20-\%20SS\%20ISO\%209004-2009.pdf, dostęp 21.03.2016

17. JACQUES M.L. 1999. The call for quality: doing right things right. “Quality Progress". September, 48-54.

18. KAYNAK H. 2003. The Relationship Between Total Quality Management Practices and Their Effects on Firm Performance. "Journal of Operations Management" 21, 405-435. 
19. KOK P., VAN DER WIELE T., MCKENNA R., BROWN A. 2001. A Corporate Social Responsibility Audit within a Quality Management Framework. "Journal of Business Ethics" 31, 285-297.

20. LASZLO Ch. 2008. Firma zrównoważonego rozwoju. Jak wypracować trwała wartość z uwzględnieniem efektów społecznych i ekologicznych. Studio Emka. Warszawa 2008.

21. MCADAM R., LEONARD D. 2003. Corporate social responsibility in a total quality management context: opportunities for sustainable growth. "Corporate Governance". 3(4) 36.

22. MICHALSKI K., SITKO J. 2012. Podejście procesowe $w$ zintegrowanych systemach zarządzania w (red.) W. Biały, J. Kaźmierczak "Systemy wspomagania w inżynierii produkcji". Wydawnictwo PKJS, 133-141.

23. MIKUŁA B., PIETRUSZKA-ORTYL A., POTOCKI A. 2002. Zarzadzanie przedsiębiorstwem XXI wieku. Wybrane koncepcje $i$ metody. Difin. Warszawa.

24. MOLENDA M. 2012. Znaczenie wartości organizacyjnych $w$ rozwoju kultury jakości. „Zeszyty Naukowe Politechniki Śląskiej. Organizacja i Zarządzanie" z.63a.

25. NAKANO C. 1999. Attempting to Institutionalize Ethics: Case Studies from Japan. "Journal of Business Ethics" 18(4), 335-343.

26. ROBITAILlE D. 2010. ISO 9004:2009 Is Out and It Sure Looks Different. „Quality Digest” http://www.qualitydigest.com/inside/quality-insider-column/iso90042009-out-and-it-sure-looks-different.html; dostęp 05.03.2016

27. RUDNICKA-REICHEL A., REICHEL J. 2012. Doskonalenie jakości organizacji $w$ wymiarze społecznym $i$ środowiskowym $w$ kontekście normy ISO 26000 w: Problemy Zarządzania (2 (37)), 84-93.

28. TARI J. J. 2011. Research into Quality Management and Social Responsibility. "Journal of Business Ethics" 102:623-638, DOI 10.1007/s10551-011-0833-x 
29. WADDOCK S., BODWELL C. 2004. Managing Responsibility: What can be Learned from the Quality Movement. "California Management Review" 47, 25-37.

30. WITHANACHCHI N., HANDA Y., KARANDAGODA K. K. W.,PATHIRAGE P. P, TENNAKOON N. C. K., PULLAPERUMA D. S. P. 2007. TQM Emphasizing 5-S Principles. A Breakthrough for Chronic Managerial Constraints at Public Hospitals in Developing Countries. "International Journal of Public Sector Management" 20, $168-177$.

31. WOLNIAK R. 2013. Spoleczna odpowiedzialność biznesu $w$ aspekcie doskonalenia systemów zarządzania jakościa. „Problemy Jakości” 9, 25 .

32. ZADEK S. 2007. The Civil Corporation: The New Economy of Corporate Citizenship. http://www.zadek.net/wpcontent/uploads/2009/12/Civil-Corporation-2nd-Edition-FirstChapter.pdf, dostęp 21.03.2016 